Scripta Neophilologica Posnaniensia. Tom XIII, strony: 211-231

Wydział Neofilologii, Uniwersytet im. Adama Mickiewicza w Poznaniu, 2013 DOI 10.7169/snp.2013.13.17

\title{
PIEKKNE TANCERKI, FANATYCZNE WIELBICIELKI, CIERPLIWE WYCHOWAWCZYNIE - KOBIETY W BARWNYM ŚWIECIE TEATRU KABUKI OKRESU EDO
}

\author{
ANNA PIECHOWIAK, ESTERA ŻEROMSKA
}

Jednym z czterech gatunków japońskiego teatru klasycznego jest (obok nō, kyōgen i jōruri/bunraku ${ }^{1}$ ) jest kabuki - ważny element kultury mieszczańskiej okresu Edo (1603-1868). Obecnie kabuki uważa się za wyłączną domenę mężczyzn, którzy na scenie z powodzeniem wcielają się zarówno w role kobiece, jak i męskie, a poza sceną zajmują się kostiumami, makijażem, oprawą muzyczną czy scenograficzną. $Z$ tego powodu wpływowi kobiet na kabuki nie poświęca się wiele miejsca w polsko- $\mathrm{i}$ anglojęzycznej literaturze. To jednak właśnie kobiety zainicjowały stworzenie kabuki i - wbrew pozorom - miały stały, znaczący wkład w dalszy rozwój gatunku.

\section{Izumo no Okuni i kobiece kabuki}

Zrozumienie zasług kobiet $\mathrm{w}$ dzieło tworzenia kabuki wymaga cofnięcia się do tanecznych źródeł tego teatru, czyli do końca XVI wieku, kiedy żyła Okuni z Izumo (Izumo no Okuni; 1571?-1613) - dość tajemnicza, legendarna wręcz

\footnotetext{
${ }^{1}$ Słowa bunraku używa się obecnie jako jedynego prawidłowego określenia profesjonalnego teatru lalkowego, którego siedzibą jest Osaka. Wszystkie inne, nieprofesjonalne formy teatru lalkowego określa się słowem jōruri (Żeromska, E. 2010. Japoński teatr klasyczny. Korzenie i metamorfozy. Tom 2: Kabuki, bunraku. Warszawa: Wydawnictwo Trio. 257).
} 
postać, o której życiu nie wiadomo wiele. Tę utalentowaną artystkę można uznać za spadkobierczynię Ama no Uzume, bogini o frywolnym usposobieniu. Z jej osobą wiążą się mitologiczne początki japońskiej tradycji tanecznej i widowiskowej.

Ama no Uzume odgrywa kluczową rolę w micie znajdującym się zarówno w Kojiki (Księga dawnych wydarzeń, 712) 2 $^{2}$ jak i Nihongi (Kronika japońska, 720). Jak można dowiedzieć się z treści tego mitu, bogini słońca, Amaterasu, urażona skandalicznym zachowaniem swojego brata, boga burzy Susanoo, ukryła się w niebiańskiej jaskini (ame-no iwayado), wejście do niej zasłoniła głazem i odmówiła wyjścia, w związku z czym cały świat ogarnęła ciemność. Aby wywabić ją z ukrycia, bogowie zorganizowali przedstawienie, podczas którego Bogini Ama no Uzume wskoczyła na przewróconą kadź i:

„tupiąc po niej, aż się roznosił huk, czyniła opętańcze ruchy: obnażyła piersi, a sznur, którym była przepasana, opuściła poniżej brzucha. Na ten widok Przestrzenie Wysokich Niebios aż się zatrzęsły, bo osiem milionów bogów jednocześnie wybuchnęło śmiechem." ${ }^{3}$

Zabiegi bóstw przyniosły skutek: Amaterasu, zaintrygowana odgłosami, wychyliła się z niebiańskiej jaskini, do której wejście bogowie pospiesznie za nią zamknęli, by nie mogła na powrót się schować. W ten sposób sprawili, że na całym świecie znów zapanowała jasność.

Okuni natomiast najprawdopodobniej urodziła się w nadmorskiej miejscowości Izumo (pref. Shimane). Była córką kapłana shintoistycznego (kannushi) w świątyni Izumo-taisha ${ }^{4}$, gdzie po latach również sama została kapłanką (mi$k o$ ). Niektórzy twierdzą jednak, że była to po prostu kobieta lekkich obyczajów (yüjo), która swoich tanecznych umiejętności używała po to, by wabić klientów. W tamtych czasach bowiem kobiety, którym nie wolno było występować na deskach profesjonalnego teatru ( $n \bar{o}, k y \bar{g} g e n)$, tworzyły wędrowne, tułacze trupy, dzięki czemu mogły łączyć sztukę aktorską z prostytucją. Uwodzicielskimi, erotycznymi tańcami wabiły klientów i skłaniały ich do korzystania z innych usług artystek. Jedną z takich właśnie grup założyła Okuni, a jej umiejętności

\footnotetext{
${ }^{2}$ Kojiki - najstarsze zachowane dzieło piśmiennictwa japońskiego, opracowane na polecenie dworu cesarzowej Gemmei. Jest to usystematyzowany zbiór legend, pieśni, genealogii i semihistorycznych i historycznych zapisków do okresu panowania cesarzowej Suiko (593-628). (Melanowicz, M. 1994. Historia literatury japońskiej. Tom 1. 88); polskie wydanie: Kotański, W. 1986. Kojiki, czyli księga dawnych wydarzeń, Warszawa Państwowy Instytut Wydawniczy.

${ }^{3}$ Kotański, W. 1961. Dziesięć tysięcy liści. Antologia literatury japońskiej. Warszawa: PWN. 48.

${ }^{4}$ Izumo-taisha - druga co do ważności świątynia shintoistyczna w Japonii. Jej patronem jest bóg Okuninushi. Jak głoszą mity, w Izumo-taisha od początku świata każdej jesieni odbywają się zjazdy wszystkich japońskich bogów (Żeromska, E. 2010. op. cit. Tom 2. 19).
} 
oczarowywały zwykłych ludzi, niezależnie od tego, czy byli zainteresowani usługami erotycznymi, czy nie. Kapłanka przenosiła się ze swoim zespołem z miejsca na miejsce, aby zyskiwać nowych widzów, ale prawdopodobnie również $w$ celu zgromadzenia środków finansowych potrzebnych na renowację głównego budynku świątyni Izumo-taisha. Nazywano ją wtedy wędrowną kapłanką, czyli aruki miko. ${ }^{5}$

Okuni wraz ze swoim zespołem odnosiła duże sukcesy: wystąpiła w chramie Kasuga-taisha w Narze, gdzie zaprezentowała taniec yayako-odori (taniec młodych dziewcząt), a także w świątyni Temmangū w Kioto, gdzie w 1603 roku w wyschniętym korycie rzeki Kamo wykonała nembutsu-odori (taniec nembut$s u)$ - taniec pochodzenia buddyjskiego, ale przesiąknięty wpływami ludowymi do tego stopnia, że zupełnie zatracił swój sakralny charakter. Jeśli wierzyć legendzie, towarzysz Okuni, Nagoya Sanzaemon (lata życia nieznane), samuraj dobrze zaznajomiony z $n \bar{o}^{6}$, nauczył ją tańców typowych dla tego teatru. Ona zaś zaaranżowała je we właściwy sobie sposób ${ }^{7}$ i w czasach, kiedy ascetyczne $n \bar{o}$ było rozrywką nie tylko niezrozumiałą, ale również niedostępną dla zwykłych, niewykształconych ludzi, dostarczyła im czegoś, co mogli pojąć i czym byli w stanie się cieszyć.

$\mathrm{Z}$ rejonu Kansai Okuni zaczęła ze swoją trupą wędrować coraz dalej na północ, odwiedzając Edo, a legenda głosi, że nawet wyspę Sado, znaną wówczas jako miejsce karnych zsyłek obywateli, którzy sprzeciwili się prawu. Nawet jeśli faktycznie Okuni dotarła na Sado, to pojechała stamtąd do Kioto, gdzie prawdopodobnie umarła i gdzie obecnie przy świątyni Daitoku-ji znajduje się jej grób, którego autentyczność potwierdza wielu naukowców. Jednakże mieszkańcy Izumo wolą wierzyć, że Okuni powróciła do Izumo-taisha i tam do śmierci w 1613 roku (w wieku osiemdziesięciu siedmiu lat) spędziła ostatnie lata życia, zajmując się pisaniem wierszy.

Artystka, będąc powodem do dumy mieszkańców Izumo, doczekała się ufundowania na jej cześć wielu lokalnych świątyń shintoistycznych i buddyjskich. Jeśli ktoś wybierze się na wycieczkę do jej rodzinnej miejscowości, może odwiedzić dom w którym podobno mieszkała, i grób, uznawany przez mieszkańców Izumo za prawdziwy. Mimo że od jej śmierci minęło prawie czterysta lat, kult Okuni nie odszedł w zapomnienie, o czym może świadczyć powołanie w 2000 roku festiwalu na jej cześć (okuni-kabuki-matsuri). Podczas tego święta najlepsi aktorzy kabuki odtwarzają wykonywane niegdyś przez nią tańce. ${ }^{8}$

\footnotetext{
${ }^{5}$ Tamże, s. 21.

${ }^{6} N \bar{o}-$ jeden z głównych gatunków teatru japońskiego. Ukształtował się na przełomie XIV i XV wieku. Jego twórcami byli Kanami (1333-1384) oraz jego syn Zeami (1363-1443).

${ }^{7}$ Earle, E. 1974. The kabuki theatre. Honolulu: University of Hawai'i Press. 165.

${ }^{8}$ Tamże, s. 27.
} 


\section{Magia Okuni}

Co niezwykłego było w występach Okuni, że wywołały tak wielki zachwyt publiczności, znajdowały tak licznych naśladowców i ostatecznie doprowadziły do wyodrębnienia się nowego gatunku japońskiego teatru?

W okresie Edo, kiedy oficjalne zasady życia w społeczeństwie zostały określone zgodnie z konfucjańską moralnością, popisy kapłanki z Izumo zakrawały na obyczajową rewolucję. Odbywały się na wolnym powietrzu na niewyraźnie określonej przestrzeni scenicznej. Tancerki występowały pośród ściśle otaczającej je publiczności. Bliskość $\mathrm{z}$ widzami umożliwiała artystkom nawiązywanie z nimi bezpośredniego kontaktu i podejmowanie wspólnych działań. Publiczność, która chętnie przechodziła na teren gry, nierzadko stawała się częścią przedstawienia. To prawdopodobnie właśnie $\mathrm{z}$ tego zwyczaju wynika utrwalane przez wieki niezwykłe poczucie bliskiej, wręcz intymnej więzi widza z artystą, więzi, jakiej nie można doświadczyć w żadnym innym rodzaju teatru japońskiego.

Tańce Okuni były przesiąknięte świadomie podsycaną erotyczną sugestią. Kapłanka, występując bowiem często w męskim przebraniu, odgrywała flirtujących z kurtyzanami gości herbaciarni. Jawność seksualnego podtekstu, bezpruderyjność i bezpośredniość wzbudzały powszechny zachwyt. Okuni dostarczała bowiem rozrywki, dzięki której widzowie mogli choć na chwilę zapomnieć o obowiązujących ich każdego dnia, narzuconych przez władze wojskowe ( $b a$ $k u f u$ ), surowych zasadach moralnego życia.

Sukcesy, jakie odnosiła kapłanka z Izumo sprawiły, że szybko znalazło się wiele jej naśladowniczek. Były to głównie kobiety lekkich obyczajów (yūjo). Ich pokazy, znane jako yüjo kabuki (kabuki prostytutek), przypominały farsę i były wzbogacone o często niecenzuralne kwestie oraz bardzo erotyczny taniec. Wiedzę o takich widowiskach można czerpać między innymi $\mathrm{z}$ pochodzących $\mathrm{z}$ okresu Edo drzeworytów, na których przedstawiono kobiety w nieskromnych strojach, tańczące z pasją i uniesionymi w górę ramionami.

Do istniejących na początku XVII wieku zespołów aktorskich należały nie tylko kobiety, ale stosunkowo powszechną praktyką było odgrywanie kobiecych ról przez mężczyzn i odwrotnie9 ${ }^{9}$ Konfucjański uczony, Hayashi Razan (15831657), skomentował te występy w następujący sposób:

„Mężczyźni noszą kobiece ubrania. Kobiety zaś noszą męskie ubrania, przy pasie mają zatknięty miecz, obcinają [część] włosów, a pozostałe pasma upinają w męski kok. Śpiewają prostackie piosenki i wykonują nieprzyzwoite tańce. Ich lubieżne głosy są hałaśliwe jak buczenie much i odgłosy cykad. Mężczyźni i kobiety tańczą i śpiewają razem. Tak dzisiaj wygląda kabuki."10

\footnotetext{
${ }^{9}$ Brandon, J.R., Malm, W.P. i D. H. Shively. 1987. Studies in kabuki. Honolulu: University of Hawai'i Press. 6.

${ }^{10}$ Tamże.
} 


\section{Na straży przyzwoitości}

Te nieprzyzwoite tańce prezentowano - do akompaniamentu muzycznego - na prowizorycznych, tylko częściowo zadaszonych scenach. Teren gry i ten przeznaczony dla publiczności był zazwyczaj ogrodzony wysokim bambusowym płotem. Widzowie, po uiszczeniu opłaty, wchodzili do środka i siadali bądź stawali na słomianych matach ułożonych po trzech stronach sceny.

Przedstawienia nie zawsze odbywały się w spokojnej atmosferze. Niejednokrotnie dochodziło do napięć, a nawet walk na widowni między samurajami, w których żyłach wrzała gorąca krew. Było wśród nich wielu rōninów ${ }^{11}$, którzy w czasach pokoju nie mieli zatrudnienia - udawali się więc do miast w poszukiwaniu nowych panów, zarobku albo po prostu rozrywki. Awantury, do jakich podczas przedstawień onna kabuki (kobiece kabuki) dochodziło między wojownikami rywalizującymi o aktorki, były postrzegane przez siogunów jako wysoce demoralizujące. $\mathrm{Z}$ tego powodu w 1629 roku kobiety otrzymały bezwzględny zakaz występowania na scenie ${ }^{12}$.

Zakaz ten nie oznaczał jednak końca teatru kabuki. Jeszcze przed jego wprowadzeniem, czyli już około 1612 roku, istniały zespoły złożone wyłącznie z młodych chłopców (wakashu kabuki). ${ }^{13}$ Po tym jak kobiety zostały objęte zakazem występowania na scenie, chłopcy, do tej pory zazwyczaj towarzyszący aktorkom w mało znaczących rolach i nie zwracający na siebie specjalnej uwagi publiczności, wyszli na pierwszy plan. Od tego momentu, tak jak kobiety wcześniej przebierały się za mężczyzn, tak chłopcy przywdziewali stroje kurtyzan, co z czasem doprowadziło do wykształcenia się emploi onnagata.

Młodzi artyści nie mieli jednak zbyt wielu okazji do doskonalenia warsztatu aktorskiego - przedstawienia te nie odznaczały się wysokimi walorami artystycznymi i służyły głównie eksponowaniu wdzięków początkujących aktorów. Męska prostytucja była bowiem powszechną praktyką w okresie Edo, a tego rodzaju przedstawienia stanowiły dobrą okazję do zwabienia potencjalnych klientów. Młodzi chłopcy występowali zazwyczaj w dwóch sztukach: o homoseksualnej miłości, w których szczególnie eksponowano naturalny urok (shudō goto), oraz w sztukach o uwodzeniu kurtyzan (keisei goto). Przedstawienia te, tak jak wcześniejsze występy kobiet, przesycone były erotyzmem, który władze uznały za demoralizujący, a nawet niebezpieczny, gdyż nierzadko dochodziło do tego, że zasiadający na widowni amatorzy chłopięcego powabu rywalizowali ze sobą o względy młodych aktorów, co często kończyło się tragicznie. W 1648 roku homoseksualna prostytucja została zakazana, nie przyniosło to jednak

\footnotetext{
${ }^{11}$ Rōnin - bezpański samuraj.

12 Tamże, s. 7.

${ }^{13}$ Tamże, s. 9.
} 
większych efektów. Ostatecznie w 1652 roku zamknięto teatry w Edo i innych miastach. W ten sposób zakończył się początkowy okres rozwoju kabuki, w którym główną rolę odgrywał erotyzm.

Pod wpływem niezliczonych błagalnych próśb właścicieli teatrów siogunat zezwolił ostatecznie na przywrócenie przedstawień, od tej pory wykonywanych wyłącznie przez dorosłych mężczyzn (yarō kabuki). Zgodę wydano pod warunkiem, że aktorzy odtwarzający role kobiece będą czesać się jak mężczyźni, czyli golić włosy nad czołem ${ }^{14}$. Ponadto aktorzy, którzy przekroczyli czternasty rok życia, nie mogli już nosić kobiecych ubrań ani fryzur. Pod koniec stulecia popularną praktyką stało się używanie peruk na scenie. Narastała również tendencja do powierzania ról żeńskich (onnagata) starszym aktorom, którzy oczarowywali widzów talentem, a nie atrakcyjnością fizyczną. W ten sposób zaczęła się rozwijać charakterystyczna dla kabuki technika przeistaczania się aktora-mężczyzny w kobietę.

Pomimo wprowadzonych w 1652 roku reform jeszcze przez kilka lat w wielu teatrach ryzykowano i dla przyciągnięcia publiczności wystawiano sztuki o uwodzeniu kurtyzan, znane jako shimabara kyōgen (sztuki kyōgen o Shimabarze $^{15}$ ). Sam teatr kabuki nazywany był często Shimabara, dopóki tego typu przedstawienia nie zostały zakazane w 1664 roku.

Wprowadzając zakaz występowania dla kobiet oraz nakładając wspomniane nakazy na yarō kabuki władze miały nadzieję na oddzielenie homoseksualnej prostytucji od kabuki. W praktyce okazało się to jednak niemożliwe, ponieważ zdołano jedynie spowodować dynamiczny rozwój artystyczny yarō kabuki, z czasem nazwanego w skrócie kabuki.

Ostatecznie represje siogunatu doprowadziły zatem do tego, że kabuki, którego powstanie zainicjowane zostało przez kobiety, przekształciło się w domenę mężczyzn. Mimo to, że zostały one wykluczone ze sceny, nie przestały jednak oddziaływać na rozwój tego teatru.

\section{Kobiety z dzielnicy teatralnej (shibai machi)}

Siogunat, jak wspomniano, dążył do odseparowania aktorów od reszty społeczeństwa. Na zasadność takiego postępowania wskazywał Ogyū Sorai (16661728) - uczony i doradca sioguna Tokugawy Yoshimune (1684-1751):

\footnotetext{
${ }^{14}$ Nieogolone włosy nosili młodzi chłopcy, dlatego ta fryzura kojarzyła się z ich erotycznym urokiem. Co pewien czas przeprowadzano kontrole w celu upewnienia się, czy aktorzy noszą odpowiednio przyzwoite fryzury. Początkowo nie wszyscy stosowali się do nakazów siogunatu: mimo że było to niezgodne z przepisami, aktorzy często ukrywali wygolone miejsce pod chustkami, a później pod kawałkami purpurowego jedwabiu, który z daleka sprawiał wrażenie błyszczących ciemnych włosów (Brandon, J.R., Malm, W.P. i D.H. Shively.1987. op. cit. 9).

${ }^{15}$ Dzielnica rozrywki w Kioto.
} 
„Ludzie łatwo ulegają wpływowi aktorów i kobiet lekkich obyczajów. Ostatnimi czasy nawet wśród przedstawicieli wysokiego stanu pojawiła się tendencja do używania ich żargonu, co właściwie uchodzi za modę, więc ci, którzy się z niej wyłamują, postrzegani są za prostaków. Wstyd mi, że tak się dzieje. Takie tendencje przyczyniają się do zaburzenia społecznego porządku. Dlatego koniecznie należy izolować aktorów i kobiety lekkich obyczajów od zwykłego społeczeństwa."16

Jeszcze przed narodzinami Ogyū i długo po jego śmierci wprowadzano rozmaite regulacje dotyczące życia aktorów, którzy jednak niezbyt chętnie się do nich stosowali. Opuszczali oni przypisane im dzielnice (shibai machi), odwiedzali herbaciarnie (chaya) ${ }^{17}$, domy kupców i samurajów, gdzie czasami pozostawali na noc. Zdarzało się nawet, że swoje przedstawienia prezentowali w innych częściach miasta. Siogunat niejednokrotnie odnawiał stare nakazy i wprowadzał nowe, ale aktorzy nieustannie je łamali.

Tymczasem przeciętnym mieszczanom artyści kabuki jawili się jako bohaterowie wnoszący odrobinę barwy do ich szarego życia. Zwykłe społeczeństwo, wbrew zaleceniom Ogyū Soraia, nie tylko nie chciało się od nich izolować, lecz wręcz przeciwnie: mieszczanie z radością i ekscytacją wybierali się do teatrów, gdzie mogli doświadczyć wyjątkowej bliskości z aktorami. Publiczność uwielbiała pojawiające się na scenie postaci dzielnych wojowników, romantycznych kochanków czy pięknych kurtyzan i utożsamiała je z aktorami. Emocje, jakie u widzów wzbudzał ich widok, nie różniły się niczym od tych, które w dzisiejszych czasach wywołują gwiazdy kina czy muzyki pop. Aktorzy ustalali ponadto kanony mody, inspirowali twórców drzeworytów, pisarzy i dramaturgów.

Poczucie bliskości $\mathrm{z}$ aktorami ${ }^{18}$ pozwalało widzom na nawiązywanie $\mathrm{z}$ nimi dość swobodnej komunikacji. ${ }^{19}$ Jedną z jej form były homekotoba (słowa uznania). Zwyczaj ich używania pojawił się w połowie XVII wieku, kiedy podczas przedstawienia odtwórca roli żeńskiej (onnagata) kierował kilka pochwalnych słów pod adresem aktora odgrywającego główną rolę męską, w chwili, gdy ten

\footnotetext{
${ }^{16}$ Earle, E. 1974. op. cit. 6.

${ }^{17} \mathrm{~W}$ okresie Edo działało wiele różnych rodzajów herbaciarni. Te usytuowane w pobliżu teatrów nazywano shibai jaya (herbaciarnia teatralna). Obsługiwano w nich gości teatrów: zapewniano możliwość odświeżenia się, zjedzenia posiłku w trakcie przedstawienia i po jego zakończeniu, a także zapraszano aktorów, by mogli pić wraz z gośćmi. W herbaciarniach teatralnych jednak, w przeciwieństwie do innych lokali tego typu, obowiązywał zakaz sprowadzania prostytutek (yūjo).

${ }^{18}$ Wynika to ze specyficznej organizacji przestrzeni w budynku teatru. Do sceny właściwej z lewej strony pod kątem dziewięćdziesięciu stopni przylega pomost hamanichi, a na potrzeby niektórych sztuk instaluje się także równoległy do niego pomost po prawej stronie, kari-hanamichi (tymczasowe hanamichi). Kiedy na przykład aktorzy pojawiają się jednocześnie na obu tych pomostach, widzowie przestają być tylko obserwatorami, a zaczynają współtworzyć przedstawienie i sami stają się bohaterami oglądanej przez siebie historii (Żeromska, E. 2010. op. cit. Tom 2. 74).

${ }^{19}$ Brandon, J.R., Malm, W.P. i D.H. Shively. 1987. op. cit. 20.
} 
pojawiał się na scenie. $Z$ czasem również każdy widz mógł podnieść się ze swojego miejsca i przerwać sztukę, by wyrazić podziw dla aktora - albo stojąc w swoim boksie, albo wchodząc na pomost hanamichi ${ }^{20}$. Dla aktorów było to niekiedy dosyć kłopotliwe, zwłaszcza gdy widz zapragnął wyrazić swoje uwielbienie $\mathrm{w}$ nieodpowiednim momencie. Kiedy na przykład aktor grający ducha został unieruchomiony w środku sceny nawiedzania przez zbyt długą przemowę widza, nie mógł po prostu zniknąć.

Mniej inwazyjną formą komunikacji były kakegoe, czyli spontaniczne okrzyki, którymi widzowie nagradzali szczególnie zachwycającą pozę albo dobrze dobraną intonację głosu. Wielbiciel mógł wykrzyknąć imię aktora lub jego yagō (przydomek rodu aktorskiego) ${ }^{21}$, choć najwyższą formą komplementu było nazwanie artysty nazwiskiem jego ojca, sugerując w ten sposób, że osiągnął tak wysoki poziom umiejętności jak jego poprzednik.

Zdarzało się jednak, że pod adresem aktorów padały także krytyczne lub pogardliwe komentarze, jak na przykład daikon (rzepa). Niektórzy widzowie, jeśli siedzieli dostatecznie blisko, potrafili nawet rzucać na scenę przedmioty. Tacy zapaleńcy musieli być jednak przygotowani na to, że jawny brak uznania dla aktora mógł zdenerwować jego zagorzałego wielbiciela i doprowadzić do bójki. Z tego powodu nierzadko dochodziło do rękoczynów wśród publiczności. Takie niestosowne zachowania zostały utrwalone na niektórych drzeworytach (ukiyo-e). Można na nich na przykład zobaczyć, jak widzowie z pierwszych rzędów okładają się nawzajem pięściami lub drewnianymi chodakami. W celu zapobiegania takim incydentom pojawiła się konieczność zatrudniania specjalnych pracowników (butaiban), którzy podczas każdego przedstawienia pilnowali porządku.

Wśród miłośników teatru działały formacje przypominające współczesne fankluby. Były to tak zwane teuchi renjū, czyli dosłownie ,grupy klaszczących w dłonie". Należeli do nich głównie handlarze i właściciele herbaciarni. Podczas przedstawienia zasiadali oni na widowni, wszyscy identycznie ubrani, i śpiewali piosenki na cześć swoich ulubieńców, akompaniując sobie klaskaniem oraz uderzaniem w drewniane kołatki.

${ }^{20}$ Takie okrzyki można usłyszeć czasem i dzisiaj w teatrze kabuki. Wznoszą je jednak zazwyczaj opłaceni klakierzy bądź pracownicy teatru, by stworzyć namiastkę atmosfery, jaka panowała na widowni w okresie Edo (Tamże).

${ }^{21}$ Każdy aktor kabuki, poza własnym imieniem, posiada także pseudonim arystyczny (gei$m e i$ ), który przejmuje po swoim poprzedniku wraz z arkanami jego sztuki, oraz przydomek rodu aktorskiego (yagō). W ciągu życia aktor zmienia pseudonim artystyczny wiele razy, a każdą taką zmianę określa się terminem shümei. Poza imieniem aktorowi przypisywany jest także numer wskazujący na to, którym jest kolejnym spadkobiercą tego samego nazwiska. Na przykład następca Ichikawy Danjurō I (1660-1704) nazywał się Ichikawa Danjurō II (1689-1758), a jego następca - Ichikawa Danjurō III (1721-1742) i tak dalej. 
Niekiedy fascynacja artystami przybierała dość skrajne formy. Najwyższy poziom szaleństwa na ich punkcie ilustruje anegdota dotycząca aktora Ichikawy Yaozō II (1735-1777), który wcielając się w rolę Sukeroku ${ }^{22}$ - bohatera sztuki o tym samym tytule, w jednej ze scen kryje się w beczce $\mathrm{z}$ wodą. Po spektaklu wodę z tej beczki butelkowano i sprzedawano jego wielbicielkom jako napój do picia $^{23}$. Sytuacja ta nasuwa skojarzenie ze współczesnymi wielbicielkami piosenkarzy, które podczas koncertów walczą między sobą o rzucony ze sceny przepocony podkoszulek czy ręcznik idola. Do wielbicielek aktorów kabuki należały nawet kobiety z wyższych sfer społecznych. Często wikłały się one w romanse ze swoimi ulubieńcami, co zdawałoby się nie do pomyślenia, wziąwszy pod uwagę surowy ład społeczny, z zasady uniemożliwiający kontaktowanie się przedstawicieli należących do różnych klas. Słynna jest na przykład opowieść o tym, jak w 1706 roku aktor onnagata Ikushima Shingorō (1671-1743) schował się w skrzyni na ubrania i został w niej sprytnie przeszmuglowany do posiadłości pana feudalnego (daimyō) w prowincji Kii, gdzie mieszkała jego ukochana, Ejima. Afera ta była brzemienna w skutki: Ikushimę złapano i skazano na więzienie, a teatr Yamamura-za ${ }^{24}$, do którego należał został zamknięty.

Zainteresowanie aktorami kabuki nie ograniczało się do podziwiania ich talentu na scenie. Tym, co fascynowało zwykłych ludzi w równym lub nawet większym stopniu, było ich prywatne życie, miłosne afery, historie rodów aktorskich i rodzinne konotacje. Starano się więc wychodzić naprzeciw potrzebom i zaspokajać ludzką ciekawość w podobny sposób jak współcześnie, czyli za pomocą plotkarskich czasopism. Za pierwsze takie czasopismo w Japonii uchodzi „Yakusha nyōbō hyōbanki” (Zbiór anegdot o żonach aktorów, 1759) - zbiór opowieści o mieszkających $\mathrm{w}$ dzielnicy teatralnej kobietach związanych $\mathrm{z}$ aktorami teatru $k a b u k i^{25}$.

Czasopismo to zostało pomyślane jako parodia popularnego wówczas yakusha hyōbanki (zbiór anegdot o aktorach) - cyklu publikacji przedstawiają-

\footnotetext{
${ }^{22}$ Sukeroku: Yukari no Edozakura (Sukeroku, czyli bliskie sercu kwiaty wiśni w Edo) - sztuka autorstwa Tsuuchi Jihei II (1683-1760), napisana w 1713 roku.

${ }^{23}$ J Brandon, J.R., Malm, W.P. i D.H. Shively. 1987. op. cit. 43.

${ }^{24}$ Początkowo w Edo działały cztery teatry: Nakamura-za, Ichimura-za, Morita-za oraz Yamamura-za. Po skandalu Ejimy i Ikushimy teatr Yamamura-za został zamknięty. Trzy pozostałe określano od tej pory jednym zbiorczym terminem edo sanza (trzy teatry Edo). (Honda K. 1980. Kabuki kanshō nyūmo. Tokio: Dankōsha. 25).

Mianem $z a$ (dosł. siedzenie) nazywano gildie handlowe, które zaczęły zyskiwać na znaczeniu w XIV wieku. $Z a$ wykształciły się z grup uprzywilejowanych do uprawiania swojego rzemiosła. Słowo za oprócz gildii zaczęło oznaczać (i oznacza do dzisiaj) także budynek teatru (Earle, E. 1974. op. cit. 5).

${ }^{25}$ Takei K. 2003. Edo kabuki to onnatachi. Tokio: Kadokawa. 16.
} 
cych sylwetki najbardziej popularnych artystów z Edo, Kioto i Osaki. Zeszyty te sprzedawano regularnie w Nowy Rok, od 1659 do 1877 roku. Nie zawierały one konstruktywnej krytyki teatralnej, a jedynie krótkie streszczenia sztuk z minionego sezonu, podsumowanie najciekawszych wydarzeń oraz omówienie innowacji zaprezentowanych na scenie. Dzięki temu można było w pewien sposób przeżyć raz jeszcze wcześniej obejrzane przedstawienia. Każdego aktora poddawano ocenie pozytywnej lub negatywnej.

$\mathrm{Z}$ czasem zaczęło powstawać wiele różnych czasopism krytycznych - o kurtyzanach, pisarzach, a nawet o ludziach nauki. Cieszyły się wśród mieszkańców Edo ogromną popularnością. Będąc zbiorem plotek i ciekawostek na temat prywatnego życia ich idoli, służyły zaspokajaniu ludzkiej ciekawości, a nie jedynie ożywianiu wspomnień, jak yakusha hyōbanki.

Do takiego rodzaju czasopism należał wspomniany „Zbiór anegdot o żonach aktorów". Jego bohaterkami są kobiety z otoczenia aktorów kabuki, zazwyczaj ich żony lub kochanki. Podobnie jak w pierwowzorze (yakusha hyōbanki) autor, nieznany z nazwiska, przyznaje każdej z nich ocenę, opisuje pochodzenie, przymioty ciała i ducha oraz rozmaite pogłoski, które mogły być interesujące dla czytelników. Życie tych kobiet - jak wynika ze „Zbioru...” - znacznie odbiegało od założeń obowiązującej konfucjańskiej moralności, którą dobrze odzwierciedlało popularne powiedzenie: za młodu kobieta jest posłuszna rodzicom, po ślubie mężowi, a gdy się zestarzeje - dzieciom ${ }^{26}$. Dzielnice teatralne były więc niezwykłymi miejscami, których mieszkanki bez skrępowania okazywały swą niezależność i indywidualizm.

$\mathrm{W}$ „Zbiorze...” zostało sportretowanych czterdzieści bohaterek. ${ }^{27}$ Nie znamy ich nazwisk, ponieważ w okresie Edo kobiety nazywano tylko imieniem, w dodatku niejednokrotnie takim samym. Dla lepszego rozróżnienia w czasopiśmie posługiwano się nazwiskami mężów, bądź ich yagō - przydomkiem rodu aktorskiego. Na przykład Omatsu, żona aktora Ichikawy Danjurō IV (1712-1778), na łamach pisma nazywana jest „Naritaya Omatsu”. Naritaya ${ }^{28}$ było bowiem yagō rodu Ichikawa.

Czasopismo zawiera podział na pięć grup tematycznych: żony, matki i młode dziewczęta hangempuku (dosł. połowiczne gempuku ${ }^{29}$ ), mononui (szwaczki) oraz kobiety nieobecne w Edo, czyli te, które opuszczały stolicę i towarzyszyły

\footnotetext{
${ }^{26}$ Japońskie brzmienie tego powiedzenia: Wakaku shite wa oya ni shitagai, kashite wa otto ni shitagai, oite wa ko ni shitagau.

${ }^{27}$ Opracowano na podstawie: Takei K. 2003. op. cit. 29-45.

${ }^{28}$ Ród ten przynależy bowiem do świątyni Narita, która obecnie znajduje się w mieście Narita, prefektura Chiba (Żeromska, E. 2010. op. cit. Tom 2. 91).

${ }^{29}$ Gempuku - tradycyjna uroczystość osiągnięcia przez chłopca dorosłości, obchodzona, gdy ukończył piętnaście lat (Takei K. 2003. op. cit. 31).
} 
mężom w podróży ${ }^{30}$. Mianem hangempuku określano kobiety, które zostawały kochankami lub utrzymankami - nie osiągały bowiem ,pełnej dorosłości” jak prawowite żony.

Terminem mononui natomiast nazywano krawcowe. Szycie było zajęciem postrzeganym jako bardziej eleganckie i wyrafinowane niż praca w kuchni, dlatego mononui miały w pewnym sensie wyższy status niż zwykłe służące. $\mathrm{Z}$ tego też powodu postrzegano je jako kandydatki na potencjalne kochanki aktorów. Krążyła nawet plotka o tym, że matką sławnego aktora, Segawy Kikunojō II (1741-1773), była właśnie kobieta zajmująca się szyciem. Kiedy zaszła w ciążę, odesłano ją do Ōji - rodzinnej wsi. Tam urodziła dziecko, które następnie zostało adoptowane przez Kikunojō i nazwane jego rodowym przydomkiem (yagō) Hamamuraya. Wszystko odbyło się zgodnie z powszechną w okresie Edo praktyką oddawania nieślubnych dzieci na wychowanie innej rodzinie, a następnie adoptowanie $\mathrm{z}$ powrotem. Zatajając $\mathrm{w}$ ten sposób, że dziecko pochodzi z nieprawego łoża, unikano skandali.

Niezależnie od tego, do której z grup należały, mieszkanki dzielnicy teatralnej wyraźnie wymykały się określonemu przez siogunat ,przeznaczeniu”. W tych wyjątkowych dzielnicach (shibai machi) romanse, rozwody i powtórne małżeństwa nie należały do rzadkości, choć wydawać by się mogło, że obowiązkiem kobiety było dochowywać mężowi wierności zarówno za jego życia, jak i po śmierci. Liczne przykłady kobiet przedstawionych w „Zbiorze...” dowodzą jednak, że wcale nie zawsze tak nie było. Choćby Otami, żona aktora Ogino Isaburō I (1703-1748), po jego śmierci powtórnie wyszła za mąż za Onoe Kikugorō I (1717-1784). Miała wtedy czterdzieści trzy lata, ale jeśli wierzyć autorowi „Zbiorze...” - w dalszym ciągu cieszyła się urodą i była porównywana do sławnego wówczas onnagaty, Nakamury Tomijurō I (1719-1786). Poza Otami na kartach pisma pojawiają się inne wdowy, a nawet rozwódki (batsuichi). Jak się okazuje, kobiety związane ze światem kabuki znacznie odbiegały od szeroko rozpowszechnionych wyobrażeń dotyczących epoki feudalnej. Ich życie nie ograniczało się do domu, pracy i wychowania dzieci. Dowodzi tego między innymi Ogin, żona aktora onnagata Arashiego Wakano (lata życia nieznane).

W roku wydania „Zbioru...” (1759) Arashi miał trzydzieści trzy lata. Ogin również była w podobnym wieku, a mimo to wyglądała zadziwiająco młodo, jakby zjadła syrenę - jak pisze autor czasopisma, odnosząc się do ludowej legendy, zgodnie z którą zjedzenie syreniego mięsa miało gwarantować nieśmiertelność i wieczną młodość. Ogin urodziła się w Osace, a gdy osiągnęła wiek dorosły zaczęła pracę w tamtejszej dzielnicy rozrywki Shimanouchi. Gejsze

\footnotetext{
${ }^{30}$ Od najdawniejszych czasów aktorzy byli wędrowcami, którzy nie posiadali stałego miejsca zamieszkania. W okresie Edo większość prowadziła już wprawdzie osiadły tryb życia, ale często wybierali się na występy także do innych miast, głównie do Kioto i Osaki (Tamże).
} 
z Shimanouchi cieszyły się sporą popularnością wśród aktorów kabuki i prawdopodobnie Ogin nie była jedyną, która za aktora wyszła. Dorastając w mieście teatru lalkowego (jōruri/bunraku), jakim była Osaka, uczyła się gry na samisenie od giday $\bar{u}^{31}$ Nogiwy Bungorō (lata życia nieznane). W 1756 roku Nogiwa udał się do Edo. Ogin zaś prawdopodobnie podążyła za swoim mistrzem do stolicy. Być może to właśnie wtedy poznała przyszłego męża. Po ślubie nie porzuciła jednak muzyki dla małżeństwa i wkrótce sama zaczęła nauczać gry na shamisenie $^{32}$. Kobiety wprawdzie nie mogły występować ani na scenie teatru lalkowego, ani kabuki, ale było pośród nich wiele takich, które dla przyjemności uczyły się gry na shamisenie i sztuki akompaniowania do przedstawień. Ogin, jako jedna z nich, po śmierci męża kontynuowała karierę nauczycielki gry na tym instrumencie. Zawodową grą na shamisenie zajmowała się również Sanogawa Osuna, a z szycia kostiumów scenicznych utrzymywały się (pojawiające się na kartach czasopisma) Hamamuraya ${ }^{33}$ Okaya oraz Tennōjiya ${ }^{34}$ Oyufu. Przykłady te burzą stereotyp kobiety zależnej ekonomicznie od mężczyzny, która nie jest w stanie samodzielnie zapewnić sobie środków do życia. Okazuje się, że wbrew pozorom mieszkanki dzielnic teatralnych bardzo dobrze sobie $\mathrm{w}$ tym zakresie radziły, a ze szczególnej zaradności słynęła kobieta nieznana z imienia, na kartach czasopisma występująca jako teściowa aktora Arashi Tominosuke I (1720-1766).

W „Zbiorze...” można znaleźć dużo informacji o kobietach pracujących w herbaciarniach (chaya), których w okresie Edo było bardzo dużo. Lokale takie były zróżnicowane pod względem charakteru. Te, które znajdowały się w sąsiedztwie teatrów kabuki, specjalizowały się w ich zaopatrywaniu. Żoną właściciela jednego z takich właśnie herbaciarni była teściowa aktora kabuki Arashi Tominosuke I. Jej mąż nazywał się Sumiyoshiya - podobnie jak lokal. Zgodnie z zapisem w „Zbiorze...”, teściowa Tominosuke całe życie spędziła na pomaganiu tym, których dotknął zły los, i że „nieskończona jest liczba osób, które uratowała, $[\ldots]$ nie oczekując nic $\mathrm{w}$ zamian"35. Wspomagała finansowo między innymi Horikoshiego Nisōji (lata życia nieznane) - autora sztuk, który dzięki niej stał się sławny, a obecnie uchodzi za reprezentacyjnego dramaturga drugiej połowy XVIII wieku. Horikoshi był pomysłodawcą zróżnicowania struktury dramatu kabuki poprzez wprowadzenie do niego jednego aktu tanecznego. Dzię-

\footnotetext{
${ }^{31}$ Giday $\bar{u}$ - kantor w teatrze kabuki. Jego odpowiednikiem w teatrze lalkowym (bunraku) jest tayu.

${ }^{32}$ Shamisen - trzystrunowy instrument szarpany, importowany z Chin do Japonii około 1560 roku (Żeromska, E. 2010. op. cit. Tom 2. 183).

${ }^{33}$ Hamamuraya - yagō rodu aktorskiego Segawa.

${ }^{34}$ Tennōjiya - yagō rodu aktorskiego Nakamura.

${ }^{35}$ Podaję za: Takei K, 2003. op. cit. 43.
} 
ki temu widzowie, zachwycając się dźwiękami muzyki pięknymi ruchami wykonawców, mogli (i nadal mogą) na chwilę oderwać się od wymagających większej koncentracji głównej akcji.

Teściowa Tominosuke przyczyniła się również do dobrobytu męża. Była to bowiem osoba bardzo pracowita, energiczna i obdarzona talentem do prowadzenia interesów. Dzisiaj dobrze by się zapewne sprawdziła jako żona marnego biznesmena, za niego zajmowałaby się firmą i cieszyłaby się uznaniem zarówno wśród pracowników, jak i klientów. Kobiety tej klasy co teściowa Tominosuke, dbając o mężczyzn związanych z kabuki i motywując ich do działania na scenie i na zapleczu, stymulowały - w sposób bezpośredni lub pośredni - rozwój tego teatru.

\section{Naritaya Omatsu - nauczycielka aktorów}

$\mathrm{Na}$ ostatnim, czyli najważniejszym miejscu ${ }^{36} \mathrm{w}$ „Zbiorze anegdot o żonach aktorów" zostaje zaprezentowana Naritaya Omatsu (1725-?). ${ }^{37}$ To właśnie ona - na tle pozostałych, omówionych w czasopiśmie, mieszkanek dzielnicy teatralnej może się poszczycić najwyższą, najbardziej pochlebną oceną. Kim była i czym sobie zasłużyła na takie wyróżnienie?

Ze „Zbioru anegdot o żonach aktorów” wynika, że Naritaya Omatsu miała wrodzony wdzięk i nienaganną prezencję. Jej imię jest symboliczne, ponieważ oznaczający sosnę (matsu) ideogram chiński ${ }^{38}$, którym się je zapisuje, składa się z dwóch elementów: drzewa (po lewej) oraz wysokiej rangi (po prawej). Oba komponenty, zestawione razem, wskazują na to, że sosna uchodzi za najbardziej szacowne spośród wszystkich gatunków drzew. Do dziś zajmuje ona szczególne miejsce $\mathrm{w}$ sercach Japończyków, którzy przyznają jej pierwszeństwo pośród trzech najważniejszych roślinnych symboli. ${ }^{39}$ Podobnie Omatsu. Zajmowała ona pozycję tak szlachetną i wysoką, na jaką wskazywało to imię. ${ }^{40}$

\footnotetext{
${ }^{36} \mathrm{~W}$ Japonii to, co najważniejsze, znajduje się zawsze na końcu. Przejawia się to między innymi w korespondencji, gdzie nazwisko adresata zostaje podane dopiero na końcu listu.

${ }^{37}$ Opracowano na podstawie: Takei K. 2003. op. cit. 146-177.

${ }^{38}$ Pismo japońskie składa się z trzech systemów zapisu: ideogramów chińskich (kanji) oraz dwóch sylabariuszy: hiragana i katakana.

${ }^{39}$ Sosna, bambus i śliwa (łącznie określane jednym słowem shōchikubai) to trzy najważniejsze w Japonii (oraz pierwotnie w Chinach) symbole roślinne. Sosna, wiecznie zielona, symbolizuje nieprzemijającą szlachetność i długowieczność, bambus - prawość, uczciwość i, ze względu na swoją giętkość - delikatność, a śliwa, która zakwita gdy jeszcze pada śnieg, jest symbolem wytrwałości i wierności pomimo przeciwności losu. Do dziś w wielu tradycyjnych japońskich restauracjach istnieje zwyczaj wskazywania za pomocą nazw tych drzew wystawności potraw: sosna to
} 
Jej przybranym ojcem był aktor Iwai Hanshirō III (1697-1759), członek rodu Iwai, do którego od pokoleń należał teatr Iwai-za w Osace. W późnych latach swego życia Hanshirō III wycofał się z teatralnej kariery i zamieszkał wraz z córką w Edo. „Zbiór...” dostarcza także informacji o prawdziwym pochodzeniu Omatsu. Jej biologiczny ojciec, Wakasa Taijō (lata życia nieznane), zajmował się w Kioto wytwarzaniem nakryć głowy. Taijō był to honorowy przydomek, jaki w okresie Edo cesarz nadawał między innymi cieślom, kowalom czy cukiernikom. W takiej oto rodzinie, mogącej poszczycić się szlachetnym nazwiskiem, narodziła się kobieta, która w z czasem miała wywrzeć znaczący wpływ na teatr kabuki.

Omatsu od dzieciństwa służyła w yashiki, czyli rezydencji arystokratycznej, znajdującej się w pobliżu Pałacu Cesarskiego w Kioto. Do jej obowiązków należała nie tylko praca fizyczna, ale także baczna obserwacja i naśladowanie manier arystokratów (kuge). Nabycie ogłady i wyrafinowania Omatsu zawdzięczała właśnie odbytej w dzieciństwie służbie w yashiki. Jej elegancja - jak odnotowano w „Zbiorze...” - dorównywała szlachetnie urodzonym damom. Ceniono jej łagodność, szacunek dla ludzi, takt i umiejętność zachowywania wyważonego dystansu. Wiodła więc harmonijne życie towarzyskie. Budziła także powszechny podziw niezwykłym zmysłem estetycznym.

Peany na temat Omatsu sprawiają, że można nabrać przemożnej ochoty znalezienia jakiejś rysy w tym doskonałym obrazie, ale autor „Zbioru...”, zapewne z pełną świadomością, popisuje się niebywałym mistrzostwem retorycznym, po to, by przekonać czytelnika o nieskazitelności tej kobiety.

Na losie kilkuletniej Omatsu zaważyła śmierć ojca, Wakasy, oraz ponowny ślub matki ze wspomnianym wcześniej Iwai Hanshirō - aktorem kabuki z Osaki. Kiedy natomiast osiągnęła osiemnasty rok życia, sama została wydana za onnagatę Segawę Kikujirō I (1714-1756), młodszego brata Segawy Kikunojō I (1693-1749), wraz z którym udała się do Edo. Ponoć wedle słów Kikujirō Omatsu była jeszcze wtedy niewinną dziewczyną, nie mającą za sobą żadnych doświadczeń z mężczyznami.

Wyjaśnienie zawarte $\mathrm{w}$ „Zbiorze...” przybliża także aspekt jej osiągnięć artystycznych, do których należała między innymi gra na różnych instrumentach, jak koto ${ }^{41}$, shamisen, shakuhachi ${ }^{42}$ czy tsuzumi ${ }^{43}$, ponadto umiejętność kompo-

zestaw luksusowy, bambus - specjalny, a śliwa - normalny (Campbell, A. i D.S. Noble. (red.) 1993. Japan, an illustrated encyclopedia. Tom 2. Tokio: Kodansha. 1401).

${ }^{40}$ Prefiks $o$ - dodawany do imion wyraża szacunek i grzeczność. Tradycyjnie dodaje się go do wielu rzeczowników (np. ocha - herbata, okashi-słodycze).

${ }^{41}$ Koto - trzynastostrunowa cytra.

${ }^{42}$ Shakuhachi - japoński flet poprzeczny z pięcioma dziurkami, wykonany z bambusa (Campbell, A. i D.S. Noble. (red.). 1993. op. cit. Tom 2. 1355). 
nowania pieśni waka, strof haikai, celebrowanie ceremonii herbacianej (sadōdroga herbaty) $i$ inne.

Zastanawia, dlaczego autor „Zbioru...” ani słowem nie wspomina o wyglądzie zewnętrznym Omatsu, skoro w przypadku wszystkich pozostałych kobiet, które opisywał, zwracał choćby marginalną uwagę na ich prezencję, postawę, kształt twarzy, na urodę. Zachowanie milczenia w przypadku Omatsu może zapewne świadczyć o tym, że nie była ona pięknością, a jawne wyznanie takiej prawdy zrujnowałoby idealny wizerunek postaci. Można też przypuszczać, że uroda Omatsu była oczywista albo tak niemożliwa do wyrażenia słowami, że nie było sensu o niej wspominać.

Wydaje się jednak, że czar tej damy tkwił nie w wyglądzie zewnętrznym, a raczej $\mathrm{w}$ jej charakterze i manierach, które sprawiały, iż nawet $\mathrm{w}$ dojrzałym wieku podbijała serca mężczyzn. Jej czar zdawał się bowiem trwalszy niż przemijająca $\mathrm{z}$ wiekiem uroda, czego dowodzi na przykład fakt, iż w 1756 roku, wkrótce po śmierci męża, trzydziestojednoletniej wówczas wdowie złożono trzy propozycje powtórnego małżeństwa. Autor „Zbioru...” nazywa ją nawet „boginią rodu Ichikawa" (Ichikawa no Okami-sama), ponieważ ostatecznie w 1759 roku zdecydowała się wyjść za Ichikawę Danjurō IV (1712-1778).

$\mathrm{Z}$ ich uroczystością ślubną wiąże się interesujący epizod, w którym istotną rolę odegrał znany z porywczości i gwałtowności aktor Bandō Sanbachi (lata życia nieznane). Wszystko wskazuje na to, że mężczyzna ten zapałał uczuciem do pięknej wdowy i bezskutecznie starał się uzyskać jej wzajemność. Rozżalony niepowodzeniem, zupełnie nie licząc się - jak zresztą zawsze $-\mathrm{z}$ opinią ludzi wokół niego, wtargnął na uroczystość zaślubin i bardzo się awanturował. Omatsu, wypełniając swój moralny obowiązek wobec żony Sanbachiego, nie odpowiadała na jego zaloty, co zapewne mocno ubodło absztyfikanta. Można sądzić, że z powodu porywczości nie zdołał przeboleć porażki i odczuł potrzebę wyrażenia swoich uczuć na oczach świadków ślubu ukochanej kobiety. Może podejrzewał, że to nie romantyczna miłość skłoniła opłakującą jeszcze zmarłego męża Omatsu do związania się z Ichikawą Danjurō IV. Miała ona w tym pewien ukryty cel. Liczyła bowiem na to, że ród Ichikawa, mający największe wpływy w świecie kabuki, udzieli wsparcia jej bratankowi, Kichijiemu (znanemu później jako Segawa Kikunojō II; inaczej: Ōjirokō). Zdaje się, że początkowo Omatsu nie była przekonana do tego pomysłu, ale ostatecznie - ze względu na przyszłość Kichijiego i rodu Hamamuraya - zmieniła zdanie. Kiedy bowiem zmarł jej mąż, pozostał już tylko jeden przedstawiciel rodu Segawa. Był nim Kichiji (1741-1773), syn zmarłego siedem lat wcześniej Kikunojō I (1693-1749), czyli bratanek Kikujirō. Dlatego stojąca pod znakiem zapytania przyszłość rodu spo-

\footnotetext{
${ }^{43}$ Tsuzumi - rodzaj małego bębenka w kształcie klepsydry, z którego dźwięk wydobywa się przez uderzanie dłonią (Tamże, s. 1636).
} 
częła w rękach owdowiałej Omatsu. Jedyną szansę ratunku stwarzało małżeństwo z aktorem należącym do wpływowego rodu Ichikawa, i choć początkowo nawet przyszły małżonek nie był optymistycznie nastawiony do tego pomysłu, ostatecznie doszło do zaślubin z Ichikawą Danjurō IV, czterdziestojednoletnim wdowcem, który wiele lat wcześniej stracił pierwszą żonę, Oinu. Syn Ichikawy, przyszły Ichikawa Danjurō V (1741-1806), był wówczas znany jeszcze jako Matsumoto Kōshirō III.

Omatsu nie była wprawdzie matką Kichijiego, tylko jego ciotką, ale włożyła całe serce $\mathrm{w}$ uczynienie $\mathrm{z}$ niego dobrego aktora. Wychowana $\mathrm{w}$ rodzinie związanej z teatrem kabuki, wszechstronnie utalentowana, zapragnęła przelać swoje umiejętności na młodego chłopca, ostatnią nadzieję rodu Hamamuraya. Kiedy Omatsu została żoną Kikujirō, mały Kichiji miał zaledwie dwa lata i dopiero zaczynał chodzić oraz wypowiadać pierwsze słowa. Na tego uroczego berbecia, nie mając własnych dzieci, Omatsu przelała wszystkie swoje uczucia macierzyńskie i zapragnęła uczynić z niego utalentowanego aktora, który stanie się sławny w całym Edo. Do urzeczywistnienia swojego zamierzenia potrzebowała patronatu wpływowego rodu Ichikawa. Mogła to osiągnąć jedynie poprzez małżeństwo.

W owych czasach wszyscy występujący w Edo aktorzy onnagata pochodzili z Kansai. Dzięki wyuczonym od dziecka manierom i eleganckiej postawie nawet podczas wykonywania zwykłych codziennych czynności roztaczali wokół siebie specyficzny, subtelny urok. Potrafili też perfekcyjnie wykorzystywać te umiejętności na scenie. Ōjirokō, jak później został nazwany Kichiji, był pierwszym onnagata urodzonym w Edo, ale dzięki Omatsu cechowała go elegancja godna mieszkańca Kioto. Omatsu uczyła go bowiem gry na koto, shamisenie i tsuzumi, a także starała się, by przyswoił on sobie tajniki stylu gry aktorów onnagata z Kansai ${ }^{44}$, których występy oglądała jeszcze jako mała dziewczynka, i których obraz pozostał w jej pamięci. Dbała o niego nie tylko jeśli chodzi o jego rozwój artystyczny: obawiając się, że popularność, jaką młody aktor cieszył się wśród dziewcząt, mogłaby przynieść kłopoty przeszkadzające mu w karierze, starała się zdusić każdy problem w zarodku.

Omatsu dobrze zaplanowała przyszłość swego podopiecznego. Znalazła mu nawet odpowiednio sytuowaną narzeczoną, Okumi, córkę aktora Ōtaniego Hirōjiego (lata życia nieznane). Podobno małżeństwo to miało być zgodne z ostatnią wolą Kikujirō, co zdawało się przesądzać sprawę: Okumi weszła do rodu Hamamuraya, a Omatsu przyjęła ją serdecznie jak własną córkę.

${ }^{44}$ Styl kabuki z rejonu Edo (edo kabuki) różni się od stylu kamigata kabuki. W Edo dominuje styl gry nazywany aragoto, czyli szorstki, gwałtowny, natomiast w rejonie Kamigata (Kioto i Osaka) popularnością cieszy się styl wagoto, który cechują miękkość i delikatność. (Honda K. 1980. op. cit. 23-25). 
Niestety nie wszystko szło po myśli Omatsu. Problemem okazało się na przykład to, że młody Ōjirokō miał rzesze wielbicielek, a niektóre $\mathrm{z}$ nich nie poprzestawały na wzdychaniu doń z widowni i podziwianiu go z daleka. Zakochana w nim bez pamięci kurtyzana Oiyo uciekła z Fukagawy ${ }^{45}$ i znalazła schronienie - czy raczej wymusiła udzielenie go sobie - w domu Ōjirokō. Ten zaś, choć miał już narzeczoną, pragnął zatrzymać również Oiyo - ku niezadowoleniu Omatsu, bo jakżeż mogłaby powierzyć ukochanego bratanka pierwszej lepszej gejszy, o której pochodzeniu nie wiedziała niczego? Musiało to dla niej być nie do pomyślenia. Omatsu, znając jednak lepiej niż ktokolwiek inny zasady rządzące światem rozrywki i wiedząc, że nie może odprawić Oiyo z niczym, z trudem przełamała własne opory i pozwoliła jej zostać. W ten sposób pod jednym dachem zamieszkała zarówno prawowita narzeczona rozchwytywanego przez panny aktora, jak i zakochana w nim gejsza, która zdecydowała się postawić wszystko na jedną kartę i odważyła się całkowicie zerwać z dotychczasowym życiem.

Ōjirokō nie był jedynym aktorem kabuki, który niemal wszystko zawdzięczał Omatsu. Dzięki jej patronatowi i wysiłkowi włożonemu w odpowiednie kształcenie młodych chłopców, w pamięci mieszkańców Edo przetrwały jeszcze dwa nazwiska sławnych onnagata. Jednym z nich był Iwai Hanshirō IV (17471800), którego ze względu na charakterystyczną, okrągłą twarz nazywano także Otafuku ${ }^{46}$ Hanshirō.

Aktor ten był więc młodszy od Omatsu o dwadzieścia trzy lata, a od Ōjirokō, z którym razem uczęszczał na zajęcia Omatsu - o sześć lat. W dzieciństwie nosił imię Matsumoto Shichizō. Opiekował się nim Ichikawa Danjurō IV, więc kiedy Omatsu została jego żoną, od razu dostrzegła w chłopcu wielki potencjał i wzięła go pod swoje skrzydła, aby zapewnić mu odpowiednie wychowanie i wykształcenie.

Omatsu wykorzystała sytuację powstałą sześć lat po śmierci swojego przybranego ojca, Iwaiego Hanshirō III (1698-1760), kiedy Ichikawa Danjurō IV postanowił wskrzesić jego imię i nadać je kolejnemu aktorowi, który - w jego przekonaniu - nie przyniósłby mu ujmy i zdobył sławę równie wielką jak jego poprzednik. To dzięki skutecznym zabiegom Omatsu wybór padł na dziewiętnastoletniego wówczas Shichizō. Bez jej poparcia Shichizō miałby raczej niewielkie szanse na dostąpienie tego zaszczytu. Pochodził bowiem z rodziny, której członkowie tradycyjnie byli związani z teatrem lalkowym, a nie kabuki. Omatsu musiała przekonać męża, że talent, który w nim dostrzegała był tak wielki, iż należało zbagatelizować niewłaściwe pochodzenie chłopca.

\footnotetext{
${ }^{45}$ Fukagawa - jedna z dzielnic rozrywki w Edo.

${ }^{46}$ Określeniem otafuku nazywano kobiety, u których dolna część twarzy, szczególnie policzki, były okrągłe, czoło wysokie, a nos krótki. Miało raczej pejoratywne zabarwienie i używano go w odniesieniu do mniej urodziwych dziewcząt.
} 
Okazało się, że i tym razem jej intuicja nie zawiodła. Szczególną sławę przyniosła Hanshirō rola w sztuce Mikazuki Osen (Osen z Mikazuki) ${ }^{47}$. Tytułowa Osen była najniższej rangi prostytutką w dzielnicy rozrywki. Mimo że zajmowała bardzo niską pozycję i zarabiała niewiele, cieszyła się urodą i niezwykłą popularnością. Przedstawienie z udziałem Hanshirō w roli Osen odniosło ogromny sukces między innymi dlatego, że utorowało ono drogę do powstania sewamono, czyli sztuk obyczajowych o tematyce współczesnej, przedstawiających życie mieszczan. W ten sposób Hanshirō odcisnął swój trwały ślad w historii kabuki.

Jeszcze jednym, ostatnim z trzech wspomnianych sławnych aktorów wychowanych przez Omatsu był Matsumoto Kōshirō IV (1737-1802), znany pod tym scenicznym pseudonimem od 1772 roku.

Genealogia tego nazwiska jest dość zawiła. Poprzednik Matsumoto Kōshirō IV, czyli Matsumoto Kōshirō III, to nikt inny jak Ichikawa Danjurō V, który narodził się ze związku męża Omatsu, Ichikawy Danjurō IV, czyli Matsumoto Kōshirō II, oraz jego pierwszej żony, Oinu.

Kōshirō IV był jedynie uczniem Ichikawy Danjurō IV, z którym nie łączyły go żadne więzy pokrewieństwa. Dlaczego zatem właśnie ten uczeń został wybrany, by odziedziczyć posiadające długą tradycję nazwisko Ichikawy IV i V?

Sprawę wyjaśnia nieco Nakamura Nakazō (1736-1790), który w Shūkaku Nikki (Zapiski Shūkaku, rok powstania nieznany) ${ }^{48}$ odnotowuje, że Matsumoto Koshirō IV cieszył się wyjątkowymi, niezrozumiałymi dla innych uczniów względami Ichikawy Danjurō IV. Prawdopodobnie jednak wynikało to z zabiegów Omatsu, która mogła nalegać, by właśnie tego chłopca obdarzyć specjalnymi względami i otworzyć mu drogę do kariery.

Historia Matsumoto Kōshirō IV jest przykładem trudnej drogi od nierządu do aktorskiej sławy ${ }^{49}$. Powszechna była bowiem - jak wspomniano - nawet męska prostytucja wśród aktorów, którzy, korzystając ze swej popularności, świadczyli także usługi poza sceną, dotrzymując towarzystwa amatorom ich wdzięków. Z Kōshirō było jednak odwrotnie: zaczynał w dzielnicy rozrywki Miyagawa w Kioto, do której został sprzedany przez wuja, ponieważ wcześnie stracił rodziców ${ }^{50}$. Tam nazwano go Kin'ya. Ze względu na to, że jego uroda

\footnotetext{
${ }^{47}$ Autorem jest Masuyama Sanbachi (lata życia nieznane).

${ }^{48}$ Nakamura Nakazō I (1736-1790) - aktor kabuki; jego pseudonim sceniczny brzmiał Shūkaku, od którego pochodzi tytuł pozostawionych przez niego zapisków.

${ }^{49}$ Newelska, M. 2011. Piękni, młodzi, kosztowni. Męskie praktyki homoseksualne w Japonii okresu Edo (1600-1868). Warszawa: Wydawnictwo Trio. 136-137.

${ }^{50}$ Kiedy ubogim chłopskim rodzinom brakowało pieniędzy, często decydowali się na sprzedanie córki lub syna do dzielnicy rozrywki. Praktykę tę kontynuowano do drugiej wojny światowej (Henshall, K.G. 1999. Dimensions of Japanese society: gender, margins and mainstream. Londyn: Palgrave Macmillan. 17).
} 
była niezwykła w porównaniu z urodą innych chłopców, a nawet dziewcząt, już w wieku dwunastu lat zaczął przyjmować klientów i szybko zyskał ogromną popularność. Jednakże skutki takiego wysiłku dniami i nocami nie dały na siebie długo czekać i już po osiągnięciu około osiemnastego roku życia Kin’ya zaczął tracić atrakcyjność i popularność. Zaczął więc przynosić zdecydowanie mniejsze zyski domu publicznego, którego właściciel, rozczarowany jakością pracy chłopca, bił go i chłostał, co - jak nietrudno zgadnąć - nie przyczyniało się do poprawy stanu zdrowia. Pewnego dnia, po sześciu latach upokarzającej pracy i otrzymaniu niezliczonych razów, Kin'ya postanowił uciec. Schronienie znalazł u Segawy Kikunojō II, czyli Ōjirokō, wspominanego wychowanka Omatsu. W ten sposób Kin'ya miał szansę rozpocząć nowe życie jako aktor. Nie do końca jednak rozstał się ze swoją przeszłością, ponieważ w rodzie Hamamuraya pełnił funkcję iroko ${ }^{51}$. Ówcześnie rody aktorskie podejmowały się opieki i promowania młodych talentów, przyuczając adeptów do przyszłego zawodu i umożliwiając im występowanie na scenie, a także dość często przymuszając do pracy „po godzinach”. Jeśli aktor był dostatecznie popularny, by przyciągać na przedstawienia tłumy widzów i przynosić teatrowi dostateczne dochody, wtedy jego obowiązki ograniczały się do występowania na scenie. Jeśli jednak nie cieszył się zbyt dużą sławą, musiał dorabiać w inny sposób. Wielu aktorów bardzo często godziło się więc na dodatkowe zajęcia poza teatrem, polegające na dotrzymywaniu towarzystwa i zapewnianiu rozrywki pijanym klientom. $Z$ tego rodzaju zobowiązań musiał się też wywiązywać Kin'ya. To co przeżył, okazało się jednak - przynajmniej według kolegów-aktorów - cennym doświadczeniem. Nauczył się ogłady i swobody w kontaktach z ludźmi. Dzięki temu w przyszłości, jako aktorowi kabuki, łatwiej mu było podbijać ludzkie serca, zdobywać popularność oraz sympatię widzów i wspinać się na kolejne szczeble kariery ${ }^{52}$.

W „Yakusha sensakuron” (Ciekawostki o aktorach., rok powstania nieznany $)^{53}$ została jednak przedstawiona inna wersja wydarzeń. Autor tego dzieła pomija całą tragiczną historię chłopca związaną z pracą w domu publicznym, ale stwierdza, że w 1743 roku chłopiec, będąc wówczas w wieku siedmiu lat, udał się z Omatsu do Edo, a rok później debiutował na deskach teatru Ichimura-za. Po śmierci Segawy Kikujirō, Kichiji razem z Omatsu przeszedł pod opiekę rodu Naritaya.

Nastoletni Kin'ya wraz z Ōjirokō i Ōtafuku Hanshirō również uczęszczał na prowadzone przez Omatsu zajęcia sztuki aktorskiej. Jego nieprzeciętny talent, który objawił się podczas tych zajęć, skłonił Omatsu do przekonania męża, że

${ }^{51}$ Iroko - młodzi chłopcy szkolący się na aktorów, którzy odtwarzali głównie pomniejsze postaci, przyuczając się do przyszłego zawodu, a jednocześnie świadcząc także usługi erotyczne.

${ }^{52}$ Newelska, M. 2011. op. cit. 137.

${ }^{53}$ Autor i data powstania nieznane. 
powinien objąć nad nim patronat. Kiedy zatem Kin’ya ukończył szesnaście lat (1772), odziedziczył sławne imię Matsumoto Kōshirō. Prognozy Omatsu co do talentu chłopca były jak najbardziej trafne. Świadczą o tym choćby odnotowane w zbiorach anegdot (yakusha hyōbanki) najwyższe oceny wielu jego występów oraz to, że - podobnie jak dwaj pozostali wychowankowie Omatsu, Segawa Kikunojō II i Iwai Hanshirō IV - przeszedł do historii teatru kabuki jako jeden z najwybitniejszych onnagata swych czasów.

Można się zastanawiać, dlaczego jednak Omatsu w ogóle zajmowała się prowadzeniem zajęć. Czy kierowała się tylko dobrobytem rodu, do którego należała? Ciekawy pogląd na temat motywów działania Omatsu przedstawia Watanabe Tamotsu (ur. 1936) ${ }^{54}$ w Musume Dōjōji ${ }^{55}$ (Dziewczyna ze świątyni Dōjōji, 1986). Podważa on powszechny pogląd, że ojcem (wychowywanego przez Omatsu) Ōjirokō był Segawa Kikunojō I, który nawiązał romans ze szwaczką pochodzącą z Ōjimury. Okazuje się bowiem, iż w 1741 roku, kiedy Ōjirokō się urodził, Kikunojō I już czwarty rok przebywał na występach w Kioto. Biologicznym ojcem Ōjirokō mógłby zatem zostać tylko wtedy, gdyby przebywał tam razem ze służącą. Oczywiście można przyjąć, że podczas występów w Kioto pragnął mieć przy sobie na wyłączność szwaczkę, która zajmowałaby się jego kostiumami scenicznymi, ale prawdopodobieństwo jest dość znikome. W dodatku informacje zawarte w „Yakusha Miotsukushi” (Wszystko o pięknych aktorach, 1731$)^{56}$ nie wskazują na przesadne zainteresowanie Kikunojō I kobietami i można raczej powątpiewać, czy darzył on służącą wystarczająco wielkim uczuciem, by zabierać ją z sobą do Kioto. Nie jest więc wykluczone, że prawdziwym ojcem chłopca był Segawa Kikujirō, brat Kikunojō, a mąż Omatsu.

Niezależnie od tego, jaką wersję o pochodzeniu Ōjirokō uzna się za prawdę, niezmienny pozostaje fakt, że Omatsu z ogromnym zaangażowaniem szkoliła na sławnego aktora zupełnie nie spokrewnionego z sobą chłopca. Więzy krwi miały dla niej bardziej znikome znaczenie niż pragnienie, aby z pąków młodych talentów mogły w przyszłości w pełni rozkwitnąć kwiaty dojrzałego aktorstwa.

Wychowana w stolicy, wszechstronnie utalentowana Omatsu nie miała możliwości wykorzystać na scenie swych umiejętności. Można przypuszczać, że gdyby nie wprowadzono zakazu występowania kobiet na scenie i zespoły onna kabuki rozwijałyby się bez przeszkód, Omatsu stałaby się artystką o wielkiej sławie. W czasach, w których żyła, nie była jednak w stanie realizować swojej pasji, więc $\mathrm{z}$ oddaniem zajęła się kształceniem i wspieraniem młodych aktorów i niejako poprzez nich prezentowała się na deskach teatru kabuki. Wychowani przez Omatsu aktorzy, choć każdy inny, odznaczali się wyjątkowym kunsztem

\footnotetext{
${ }^{54}$ Watanabe Tamotsu (1936-) - japoński badacz i krytyk teatru kabuki.

${ }^{55}$ Książka Watanabe Tamotsu nosi ten sam tytuł, co znana sztuka kabuki.

${ }^{56}$ Autor nieznany.
} 
i stylem charakterystycznym dla swojej nauczycielki, prawdopodobnie pragnącej w taki zakamuflowany sposób manifestować własny talent w społeczeństwie, w którym teatr był przeznaczony wyłącznie dla mężczyzn. Poszukiwanie sposobu artystycznego spełnienia przez kobietę, której odebrano do tego prawo, można chyba zatem uznać za najważniejszy cel życia Omastu. Prowadzone przez nią zajęcia miały urzeczywistnić właśnie to głębokie pragnienie.

Podsumowując, na kartach historii kabuki poza pseudonimami scenicznymi sławnych aktorów zapisały się także mniej znane nazwiska kobiet. Bez nich kabuki prawdopodobnie nie byłoby takie, jakie jest dzisiaj. Począwszy od Izumo no Okuni, prekursorki tego teatru, poprzez jej liczne bezimienne naśladowniczki, aż do Naritaya Omatsu - niespełnionej artystki, której wielu aktorów zawdzięcza nabycie cennych umiejętności i możliwość rozwinięcia talentu - kobiety w okresie Edo wywierały nieoceniony wpływ na rozwój teatru kabuki.

Uwielbienie dla gwiazdorów kabuki, zainteresowanie ich życiem i emocje, jakie budziły odgrywane przez nich postaci, zwłaszcza kobiece, pozostały niezmienne od czterystu lat. W okresie Edo, zupełnie tak jak dzisiaj, możliwość wchodzenia w świat teatralnych idoli była dla zwykłych ludzi ucieczką od przyziemnych spraw i dodawała nieco kolorytu szarej codzienności. Dlatego i dawniej, i obecnie widzowie chętnie sięgają po plotkarskie czasopisma i chłoną każdą, nawet niekoniecznie prawdziwą, informację o swych sławnych ulubieńcach, a pragnienie zbliżenia się do nich, zwłaszcza do aktorów specjalizujących się w odgrywaniu kobiecych postaci (onnagata), przybiera niekiedy skrajne formy.

\section{Bibliografia}

Brandon, J. R., Malm, W.P. i D.H. Shively. 1987. Studies in kabuki: its acting, music, and historical context. Honolulu: University of Hawai'i Press.

Campbell, A. i D.S. Noble. (red.). 1993. Japan, an illustrated encyclopedia. T. 1-2. Tokio: Kodansha.

Earle, E. 1974. The kabuki theatre. Honolulu: University of Hawai'i Press.

Henshall, K.G. 1999. Dimensions of Japanese society: gender, margins and mainstream. Londyn: Palgrave Macmillan.

Honda Kinzō. (red.). 1980. Kabuki kanshō nyūmon (Wprowadzenie do oglądania kabuki) Tokio: Dankōsha.

Kotański, W. 1961. Dziesięć tysięcy liści. Antologia literatury japońskiej. Warszawa: PWN.

Melanowicz, M. 1994. Literatura japońska. Tom 1: Od VI do połowy XIX wieku. Warszawa: Wydawnictwo Naukowe PWN.

Newelska, M. 2011. Piękni, młodzi, kosztowni. Męskie praktyki homoseksualne w Japonii okresu Edo (1600-1868). Warszawa: Wydawnictwo Trio.

Takei Kyōzō. 2003. Edo kabuki to onnatachi (Kabuki z rejonu Edo i kobiety). Tokio: Kadokawa.

Żeromska, E. 2010. Japoński teatr klasyczny. Korzenie i metamorfozy. Tom 2: Kabuki, bunraku. Warszawa: Wydawnictwo Trio. 
